UDC 141.72:305-055.2[165.2:82-3]

\author{
A. O. MUNTIAN ${ }^{1 *}$ \\ ${ }^{1 *}$ Dnipro National University of Railway Transport named after Academician V. Lazaryan (Dnipro, Ukraine), e-mail \\ muntonya@gmail.com, ORCID 0000-0001-8375-4067
}

\title{
PHILOSOPHICAL REPRESENTATION OF FEMALE ARTISTIC IMAGES IN OBJECTIVISM
}

Purpose. Based on actualization of gender discursive features, the current piece aims to clarify and accentuate the manifestation of gender-philosophical ideas interaction: feminism in the framework of objectivism. The source material for the current article is a novel by Ayn Rand "Atlas Shrugged", which is a philosophical work on objectivism. Theoretical basis. The development of the gender discourse, in particular the discourse of feminism is researched from the retrospective angle. This piece is an attempt to underline peculiarities of female artistic images representation in Rand's work and the way Rand's novel influenced the logical development of feminist discourse. Discourse of feminism is a rather peculiar notion for Objectivism, where the notion of gender is, theoretically, annihilated as far as gender is irrelevant for both personal and professional growth, however, practically, gender representation and actualization is ubiquitous in Rand's philosophy. Originality. The distinctive features of gender discourse in Objectivism are highlighted in this piece; the results are based on the application of comparative analysis. It is argued that philosophy itself may well be perceived through a literary work of fiction, thus making artistic images prototypes of philosophy functionaries. Conclusion. "Atlas Shrugged" is not merely a literary fiction, but rather a philosophical treatise on Objectivism, which is a philosophy of individual struggle and achievement. The main female protagonist of "Atlas Shrugged", Dagny Taggart, is a staunch supporter of Objectivism. In Rand's opinion Dagny Taggart is a prototype of a true woman of utopian American capitalist society, and it is her artistic image that was misinterpreted by supporters of feminist movement ideas and Dagny Taggart became an icon of feminism, whereas in reality Dagny's discourse is rather a discourse of femininity, for Dagny despises everything that is connected with feminist ideas and practices, and, it is an error to weave her discourse into a much wider feminist discourse.

Keywords: gender; discourse; feminism; femininity; philosophy of objectivism; philosophical representation

\section{Introduction}

By the end of the $20^{\text {th }}$ century the majority of academia representatives, one way or another, turned towards operating within the framework of a plenty of discourses: political discourse, economic discourse, mass media discourse, gender discourse and the last, but not the least, feminist discourse. In the end of the $20^{\text {th }}$ century, Deborah Cameron (1992), a renowned feminist scholar, writing about connections between linguistic theory and feminism, challenged the mainstream scientific community, permeated by male members, and stated that linguistic practices were implicated in mainstream ideology of patriarchate and oppression. Women's Liberation Movement, Suffrage Movement or Feminist Movement as social and political movements, scientifically have always recognized the importance of language, both theoretically and practically.

The information on the exact time of origin of Feminist Movement may vary, though it is planned to take into account the hypothesis that the Women's Liberation Movement originated in 1967 - 1968 in Chicago, where five groups of women gathered in May to realize that they were those, who were forming history. Along with this group, similar entities began to spring up around the United States at the time (Evans, 2015). The first, the second and the third waves of feminism became extremely popular in the United States and women started their fight for equal rights, which later transformed into the fight for gender equality. Ayn Rand found her way into the collective memory of feminist movement and even became a symbol of this movement to many unenlightened. Rand's novel "The Fountainhead" is the source that originated a quote, which later be- 
came an unofficial slogan and motto for numerous feminists around the world. The famous quote is: "The question is not who is going to let me, it is who is going to stop me" (O’Connor, 2014). It is worth saying that this phrase was a result of a mixed dialogue between Howard Roark and his dean in the school of architecture, also male, and had no connection to feminism. However, in my opinion this misunderstanding could happen, because the main female character of the novel "Atlas Shrugged" Dagny Taggart can be easily identified as the one whom such quote may belong to. In a number of interviews Ayn Rand stressed out that she was a male-chauvinist and her true ideas were misconstrued by the members of the feminist movement. Nevertheless, is it possible for an idea of a male-chauvinist to be so much accepted by feminists? What led to the transformation of the ideas of individualism and objectivism into feminist discourse? Which female artistic images of the novel "Atlas Shrugged" has become symbols of feminism, if any?

\section{Purpose}

The purpose of this piece is to analyze manifestation, representation and verbalization of female artistic images in the novel "Atlas Shrugged" by Ayn Rand from the philosophical point of view as well as from the point of view of gender studies; to make an attempt to dispel misconception regarding Rand's feministic views and research gender actualization in her work. I argue that Rand's fiction is the manifestation of her philosophical ideas; it is the field of objectivism notions interaction, thus there is no place for misconception of gender, i.e., feministic peculiarities of the female artistic images should be studied.

\section{Statement of basic materials}

Skye C. Cleary (2015), the author of "Existentialism and Romantic Love" mentioned that philosophers prefer taking an easy way of condoning Rand and not taking her philosophy seriously. Moreover, she pointed out another issue that scientific community has to deal with - people take Rand's philosophy seriously, thus scientific community is left no other choice - it needs to reconsider its attitude towards objectivism. Today, those who are interested in Rand's philosophy may turn to the Ayn Rand Institute, which was established few years after her death in California. The Ayn Rand Institute is an active donor to a number of colleges. However, one of the requirements for funding is that professors should be well acquainted with Rand's philosophy (Objectivism) and "Atlas Shrugged" should be compulsory reading (Cleary, 2015). Thus, it proves my point that "Atlas Shrugged" is not a simple fiction work for light reading, but a philosophical novel, and to a great extent a philosophical treatise on Objectivism, and should be analyzed as such. The philosophical system of Objectivism was constructed and developed by rand and later perfected and structured by Leonard Peikoff. Primarily for Rand this philosophical trend was championing of a man as a hero; in Objectivism people have their own happiness, aims and what is more important reasoning for accomplishing their goals. Main absolutes of Objectivism are individualism, reason and noblest activity. According to Peikoff (1989), Objectivism is considered to be a "closed system" that is formed and cannot undergo changes. The characters in "Atlas Shrugged" are not solely artistic images; they are manifestations of Rand's philosophical ideas and other philosophical notions and concepts, that is why Rand's attitude to the characters of the story may equal her attitude to the notions and concepts that are embodied in those characters and manifested through their discourses.

It is also difficult to disagree with the statement that Rand's ideas seem to be extremely radical and thus many see them as parody and criticize them. Rand's idea of blame lies with blaming 
the self - if someone has no power, it is his or her fault; there is no one else to blame, but yourself. This idea is one of the bases of capitalism and modern politics, when politicians blame the poor for being poor. Rand strongly believes in triumph of capitalism values, such as lack of altruism, self-esteem, hard work, goals achieving, etc. She despises public servants, government regulations, because they primarily are connected with stagnation and degradation, while Rand champions progress and technical development. She despises regulations and vouches that a prosperous community can be set up only without government regulations - she describes such community functioning on the example of a cult-like settlement, set up by a renegade John Galt. William Irwin (2015), a libertarian philosopher, in "The Free Market Existentialist" introduced an adapted version of Rand's philosophy, where he admitted the possibility of government control in such spheres as national security and law enforcement. Rand's extreme idea of personal responsibility leads us to the point where gender theory breaks down: Rand does not differentiate people by their gender; in fact, it is worth saying that gender category does not play any significant role in her works. Her championing of feminism was misconstrued, as far as she was far from doing that. However, despite being a male-chauvinist she paid much attention to her female characters, in particular to those female characters that mattered to her philosophical ideas. One of these female characters is Dagny Taggart, she is a leading female character in "Atlas Shrugged": "I think that your sister is awful. I think it's disgusting - a woman acting like a grease-monkey and posing around like a big executive. It's so unfeminine. Who does she think she is, anyway?" (Rand, 1996, p. 314). Rand carefully chooses the wording when she describes Dagny through others characters' utterances. The author leaves everyone undoubted about the fact that she has great respect towards Dagny, who works very hard and whose aim is to achieve success and become an integral and significant part of the scientific progress and money-making process. In my humble opinion, Rand wishes to identify herself with Dagny, she sees her character as the embodiment of a real woman, however for Rand a real woman is not the one who fights and want to be equal to a man, but the one who gains a pleasure of control through giving pleasure of control to a man; a real woman is a woman who can dominate through submission, the one who is ready to sacrifice: "It's disgusting, the way you let that conceited punk order you about. He can twist you around his little finger. You haven't any pride at all. The way you run when he whistles and wait on him! Why don't you shine his shoes? "Because he hasn't told me to," - she answered" (Rand, 1996, p. 198).

If Dagny Taggard is identification of features that Rand respect and reckons pertinent to a true woman, we may as well consider Dagny to be the female protagonist of the novel, whereas Lillian Rearden is the female antagonist. Lillian is everything what Rand believes to be boring and mediocre. At the first glance Lillian is absolutely pointless and useless even as an antagonist: she does not bring anything to the plot development. However, thinking so would be a misconception, as far as Lillian is a perfect background for the author to depict Dagny in the proper light. Dagny is the female embodiment of Objectivism, a self-made woman, who fights tooth and nail to achieve the set goals, whereas Lillian is a mediocrity, the manifestation of boredom and stagnation: "The punishment she had wanted to inflict on him was the torture of shame; what she had inflicted was the torture of boredom" (Rand, 1996, p. 57). As it has been mentioned before, treating "Atlas Shrugged" solely as fiction does not seem pertinent. Regardless of the fact, that Ayn Rand published nonfiction books such as "Capitalism: The Unknown Ideal" and "The Virtue of Selfishness", "Atlas Shrugged" deserves to be considered not only as a fiction novel, but a philosophical treatise as well, as far as it also delivers main postulates of Objectivism, Rand's philosophy of individualism, with reign of rational. As Ayn Rand said: "My philosophy, in es- 
sence, is the concept of man as a heroic being, with his own happiness as the moral purpose of his life, with productive achievement as his noblest activity, and reason as his only absolute" (Rand, 1996, p. 1218). The morale of Rand's philosophy is to value individualism and to do whatever it takes to become successful and achieve good results, it may be said that Objectivism proclaims total freedom and individualism at any cost. In Objectivism ends justify the means, if in the result a man achieves his goals. In Objectivism there is no place for dualism, and this is the basic feature that opposes Rand to Kant and his categorical imperative. The Golden rule or the categorical imperative is the central philosophical concept introduced by Immanuel Kant in his piece "Groundwork of the Metaphysics of Morals". This work is one of his first substantial philosophical works on moral philosophy, where he argues that the moral law ought to be carried with it absolute necessity. He points out that content and inception of the moral imperative do not differentiate in accordance with circumstances. Thus, it is assumed that if the moral law exists it must be universal and omnipotent and can be investigated exceptionally through prior rational reflection. Therefore, a justified theoretical understanding is impossible without metaphysics of morals (Paton, 1962). As it has been mentioned, under the circumstance that the moral law exists it ought to be applied universally and, thus, it can never rely on hypothetical imperatives that can be applied if somebody has a specific end. In other words, if the imperative is associated with the moral law, it absolutely must be categorical. Regardless of the ends a person may hold and of their variations, the categorical imperative holds for all rational agents. If it is found, the categorical imperative should provide humanity with the moral law. Kant believes that the categorical imperative must be based on the notion of the law itself as far as laws apply universally, thus, this is the only option we are left with. From this observation, Kant derives the categorical imperative, which requires that moral agents act only in a way that the principle of their will could become a universal law. When generalizing the understanding of the categorical imperative, it can be said this imperative is the way Kant perceived the principal of morality, whereas Rand denies the ruling of any restrictions both from society and government, she detests collective morality and cannot stand making decisions under influence of society norms. She champions freedom and individualism, and emphasizes that only by acting on his own will and accord and achieving personal goals can a man be happy, thus creating a happy society.

As a philosophy Objectivism was interacting with other philosophical thoughts and, for that matter, underwent and still undergoes comparative scientific analysis. In the $20^{\text {th }}$ century philosophy stopped being purely metaphysical and acquired a number of sociological, economical and other features. Nevertheless, a great deal of attention is still being paid to the image of man, and functioning of this image in different spheres of life. Despite her preferences, living in the $20^{\text {th }}$ century both Rand and her philosophy were influenced by existentialist school of philosophy. Being different on a greater scale from existentialism, objectivism shares some common points with this philosophical line of thinking, especially because there is no concord between leading existentialists themselves on a number of crucial philosophical points. What can be said for sure is that there are definite similarities between Rand and Nietzsche, especially on the point of omnipotence of the man. They both criticize Christian moral and perceive Kantianism as embodiment of Christian ethics in secular life. Both Nietzsche and Rand denounce altruism and believe that altruism is a sign of decay, however Nietzsche believes that, though being able to function in altruistic society, a talented individual will not be able to achieve positive results, whereas Rand is strongly convinced that a determined individualist is able to achieve a set goal and get the upper hand over a leftist society. Nevertheless, Rand and Nietzsche disagree on an extremely important issue for Objectivism, which is reason. Nietzsche (2007), without a doubt, acknowledges 
men of science, considering them to be superior beings; however, he supposes that a man is guided by primordial feelings rather than by rational thinking. Rand believes that a man has a freedom to choose, a man has free will, she denies causality and states that future is not determined by the past, this is the crucial point on which Rand agrees with Sartre. Apart from that they agree on such an important issue as the necessity for a man to create his own values, a man must develop his own enterprises, whether they may be intellectual, economical, political, or any other. What matters is the idea of a free personal choice (Sartre, 1956). These are the points of views similarities between Rand and Camus as well. Camus (1942) assumed that a man's life was the most precious thing in the world, and the power of man was measured by his desire to fight against irrationality of living and conquer this irrationally through arduous fight. He was championing freedom, may it be an absurd one. The most intriguing is comparing Objectivism to Heidegger's philosophy. At the first glance it seems there is nothing in common. Heidegger (1962) champions and celebrates the category of "Being", and thus denies "Reason", which is a prime category for Rand. Apart from differences in the point of view on Reason, they could not come to terms regarding a number of other issues, such as technological advances (Heidegger was in the opposition to the possibility of controlling nature through technology), ethno-cultural expression of a personality and others. Attitude to individuality was another thing that greatly opposed Rand's philosophy to Heidegger's thinking. Heidegger fathomed that individualism was impossible as was impossibly absolute individuality, whereas for Rand individualism and individuality were not simply important, they were cornerstone prerequisites for self-content, happenings, achieving results and progress itself. Heidegger believed that a human's "Being" could exist only under the circumstance of tight connecting to other human "Beings", those "Beings" influence one another continuously, thus making individualism impossible in any result. He was a supporter of cultural relativism and believed that the true meaning can be reached only through the original culture. However, it is worth saying that Heidegger was a rather controversial figure in the philosophy of the $20^{\text {th }}$ century. In the beginning his interest was primarily lying with assessing of the "Being" through phenomenology, and after the "Turn" it shifted into the realm of linguistics: language became the crucial tool for Heidegger through which he might be able to reveal the question of existence. And this is the point where his and Rand's thinking overlap. At some moment they both turned to language as a means through which main philosophical categories could be analyzed, interpreted and relayed to others. Heidegger, though he claimed that his philosophy was free of politics, later overshadowed his philosophy with political insights and views and followed the path of developing political discourse, while Rand got involved in feminist discourse among some others.

Ayn Rand is largely perceived to be a feminist and women's rights fighter mainly because of the discourse of her two main female characters: Dominique Francon from the novel "The Fountainhead" and Dagny Taggart from the novel, or philosophical treatise on Objectivism. These characters are successful, determined, they know what they want to achieve, whom and what they want to become; they set goals and achieve them. They are beautiful, attractive and strong they are winners, rather than victims of modern society regulations. These women fight for what rightfully belongs to them.

Most of the men had seen her many times. Looking at her, as she raised

her head, many of them thought-in astonishment and for the first time - 
that the face of their Operating Vice-President was the face of a woman

and that it was beautiful. Someone in the back of the crowd cried sudden-

ly, cheerfully, ‘To hell with Jim Taggart! (Rand, 1996, p. 213)

This is Dagny Taggart's discourse - the discourse of beauty and power combined on the background of general respect, especially on the part of male subordinates. However, it is contorted understanding of feminist ideas, primarily, because Dagny Taggart is a staunch supporter of individualism, which is impertinent to feminist ideology. Lillian Rearden, Hank Rearden's wife, is Dagny's counterpart, and the main female antagonist of the novel, however even for a villain she is not much capable of doing anything significant or dramatic. Nevertheless, Lillian's character is of vital importance for a number of reasons and the basic one is that Lillian is a personification of everything Ayn Rand cannot accept as relevant. Lillian is trying to control her husband by reproaching him, threatening him and denying him his every wish; she does not understand him, she wants him to live in her paradigm, where he should be an ordinary husband, while he is anything but ordinary. At some point, having become disappointed with his wife's ability to support him Hank gives up on quality of their family life: "Oh, that's right, I did. I'm sorry. But today at the mills, we poured-" He stopped; he did not know what made him unable to utter the one thing he had come home to say; he added only, "It's just that I forgot"(Rand, 1996, p. 91). Lillian is depicted as a typical woman, suffering because of her husband's neglect and being supported by all other women of the family. She wants him to be interested in her; however, she demands that without any grounds. She wants to be respected without doing anything, but verbally expressing her wish, and she sincerely believes that her wish should be universally accepted and fulfilled. Overall, Lillian verbalizes basic postulates of feminism - she demands her desires and rights to be exercised and refuses to fulfill any obligations on her part. She denounces hard work; she does not have any ambitions apart from having limitless power without paying effort. Lillian is the supporter of collective leftist ideology which has nothing to do with Objectivism, where a woman is seen as able human being equal to man in regard of strength of fight they will have to put up to achieve the results they want and to succeed in a way they want. Rand makes no difference between a man and a woman, and does not see it possible to differentiate people regarding their sex or gender. In this regard it is highly unlikely for Rand to proclaim any leftist feminist postulates. In terms of Objectivist a fight for happiness and success means that an individual need to work hard and most often alone without attracting attention and throwing ungrounded demands (Muntian, \& Shpak, 2015).

Rand pointed out that a line of work was not important, neither for a man, nor for a woman. As long as an individual could achieve personal growth and satisfaction in his or her career, this individual was a success for Rand. That is another thing that will never let Ayn Rand to be enlisted as a feminist, as far as her idea was, and Dagny Taggard is a personification and embodiment of this idea, that regardless of sex or gender an individualist can be great and a "collective bio matter" will fail - both Lillian Rearden and Jim Taggart failed miserably. People who believe that there is collective good, which should be shared, are doomed to fail; people who believe that results can be achieve without hard work, determination and great personal sacrifice are doomed to fail. A woman can achieve greatness through any work: through her character Dagny Taggard, who is speaking with a woman who works in the shop, Rand says that if a woman chooses to be a mother she can be great in this vocation, if she chooses to be a shop assistant, she can be great 
in this line of work. The position, title, post is not important what matters is desire to work, to construct, to produce, the work itself is what matters. Rand give a woman free choice, she says that a woman can be great in what she does:

"They represent my particular career, Miss Taggart", said the young

mother in answer to her comment, wrapping a loaf of fresh bread and

smiling at her across the counter. "They are the profession I’ve chosen to

practice, which, in spite of all the guff about motherhood, one can't prac-

tice successfully in the outer world...". (Rand, 1996, p. 989)

Rand's idea is that maternity is a full time occupation; it is a profession, not merely vocation and a woman should have a free choice in order to start this career. In this regard, Objectivism may have slight correlations with feminist discourse, however this correspondence is rather weak to name Rand a feminist and proclaim feminism and Objectivism alike.

At the time when Rand was working on "Atlas Shrugged" the second wave of feminism broke out. It was the time of the rise of left or socialistic movements and those who were fighting for the rights of the poor, were fighting for the rights of women as well, in fact, even for the leftist ideology women were perceived as incapable beings, compared to those with special needs, either physical or emotional. Rand in her turn, fiercely supported capitalism, individualism and strongly opposed altruism of any kind. Thus, she considered feminists, who were supporting leftist ideologies and collective good opportunities, to be germs that chose to live at the expense of the others and avoided personal responsibility; they argued that they needed privileges from the society, offering nothing in return. It seems that in Rand's opinion Lillian Rearden and Hank's mother were typical feminists - they thrived on Hank's success, condemned his success and did everything in their power to stop him from being successful (Muntian, \& Shpak, 2015). Lillian constantly reproached Hank, though had no intention to start living without his money: "You're not interested in any of us or in anything we do. You think if you pay the bills, that's enough, don't you? Money! That's all you know. And all you give us is money. Have you ever given us any time?" (Rand, 1996, p. 40). It is highly unlikely that Objectivism has much in common with any of the waves of feminism. However, what should be taken into account is the concept of the feminine self representation in the framework of gender studies. As far as discourse is far from being solely linguistic category, femininity discourse should be analyzed as opposition to feminist discourse (Muntian, \& Shpak, 2015). For Ayn Rand Dagny Taggart is a true woman, a real female being. She is the one of utmost integrity - she is determined, she is successful, she is the one who possess integrity of her mind and body. I strongly believe that Rand ascribed Dagny with idealistic features of a true woman: Dagny is respected by everyone, she is physically attractive, she is clever, and she has values. However, what makes her a real woman is ability to sacrifice her utmost power and being capable to surrender: "Whatever I am, she thought, whatever pride of person I may hold, the pride of my courage, of my work, of my mind and my freedom that is what I offer you for the pleasure of your body" (Rand, 1996, p. 472). Dagny Taggart's artistic image is a way for Rand to portray a utopian woman. Dagny is a woman who does not believe that fight against men is productive. The same issue was relevant to Rand; she simply did 
not see any point in fighting with men. She did not believe that her rights were infringed and need to be either protected or fought for. Ideal woman for Rand is someone who exercises every right she has and achieves results; she is a woman who does not whine and expects someone to help her; Rand's ideal woman is a woman who does not see gender inequality; she is a woman with self-respect and she is a woman aware of her sexuality:

Is that what you want? Is it as simple as that? - she thought, but knew

that it was not simple. There was some unbreakable link between her

love for her work and the desire of her body; as if one gave her the right

to the other, the right and the meaning; as if one were the completion of

the other — and the desire would never be satisfied, except by a being of

equal greatness. (Rand, 1996, p. 195)

Sexuality is another taboo for feminist discourse. Sexuality should not be advertised: in the fight for equality there is no place for sexuality. Dagny's artistic image falls along the line of feminist discourse, while she is wearing a short haircut and trousers, however, it ends, where Dagny starts using her femininity and sexuality. Today the definitions of feminism are numerous, and differences between feminism and femininity are not cleared and structured yet. How to draw that line is still a question without answer. What can be said for sure, it is not difficult to read Rand's characters in the light of feminist discourse: Dagny is ambitious and powerful woman, and anyone would like her to be an endorsement of this or that point of view. However, one should be careful, as far as the scientific background and justifications for an artistic image may vary.

\section{Originality}

In the current period there is the number of scientists who work on the topic of gender studies, the fewer of them research the problem of gender studies from the philosophical points of view, and even fewer deal with comparative analysis of feminist discourse in Objectivism. In this investigation I attempted to analyze feminist discourse functioning in Objectivism and touched upon the notion that a fiction novel may be regarded as a philosophical treatise, argued that Ayn Rand, the founder of Objectivism, was not a staunch supporter of feminism, as far as being an individualist she could not support feminist leftist ideology.

\section{Conclusions}

Objectivism is Ayn Rand's philosophy, which originated in the middle of the $20^{\text {th }}$ century, whose one of the main treatises is a work "Atlas Shrugged". The main features of Objectivism are individuality and progress. "Atlas Shrugged" is a symbol of American utopian capitalism.

Being a supporter of Greek philosophy, especially Aristotle, Rand addressed the topics of Greek mythology in her work as well, naming her work "Atlas Shrugged". Rand believed that humans are like atlantes and under certain circumstances, having tuned their brain power and energy in the right direction, they can achieve tremendous results. The main hero of Rand's epos 
is a white male, capable of committing great deeds, thus attributing "Atlas Shrugged" to the symbols of feminist discourse is, in my opinion, misconception.

In the course of studies, I come to the conclusion that Rand's ideas on femininity were misconstrued and misinterpreted as feminist discourse, while Rand herself was enlisted into the feminist movement. I also come to the conclusion that from a philosophical point of view Rand's main characters, such as Dagny Taggart and Dominique Francon, are not under any circumstances figures of feminist discourse, though they may seem as such. Objectivism is a philosophy that denounces leftist collective ideas of equal rights; Objectivism proclaims the goods of fight and personal growth, the ideas of individualism and desire to achieve great results against all odds; Objectivism champions individuality and level of personal achieving is primarily connected to one's individuality rather than societal regulations. On the other hand, I come to the conclusion, that despite being a male-chauvinist Rand managed to create an image of an ideal woman, and that very image misled feminist community and led them to believing that Rand supported feminist ideals. Dagny Taggart's artistic image ignited a number of debates. In my opinion, the key to solving the riddle lies within depths of Rand's philosophy - to understand Dagny Taggart's discourse of femininity, rather than feminist discourse (Muntian, \& Shpak, 2015), one should understand Rand's philosophy, which is antithetical to feminist discourse. Having analyzed the number of scientific works and philosophical ideas peculiar to the XX century, the following conclusion has been reached: literary works, especially those that contain direct philosophical meaning (such as the representation of the postulates of Objectivism - Ayn Rand's philosophy once again introduced in the novel "Atlas Shrugged") should not be analyzed separately and independently, but within the framework of the philosophical currents to which these literary works belong, as well as in accordance with the socio-humanitarian method of theorizing, which focuses on the cognitive strategy of knowledge (V. Dilthey, G. Simmel, M. Weber). Regarding the discursive analysis, it is worth saying that both feminist discourse and discourse of femininity in Rand's works should be studied exceptionally through the prism of Objectivism philosophy, to avoid misconceptions of the kind.

\section{REFERENCES}

Cameron, D. (1992). Feminism and linguistic theory. Great Britain: Palgrave McMillan. (in English)

Evans, S. M. (2015). Women's Liberation: Seeing the Revolution Clearly. Feminist Studies, 41(1), $138-149$. Retrieved from https:/www.bu.edu/wgs/files/2015/04/FS41-1_Sara_M._Evans-1.pdf (in English)

O’Connor, M. (2014). Ayn Rand, Girl-Power Icon. The Cut. Feminism. Retrieved from https://Www.Thecut.Com/ 2014/11/Ayn-Rand-Girl-Power-Icon.Html (in English)

Cleary, S. (2015). Philosophy Shrugged: Ignoring Ayn Rand won't make her go away. Newsletter. Retrieved from https://aeon.co/ideas/philosophy-shrugged-ignoring-ayn-rand-wont-make-her-go-away (in English)

Irwin, W. (2015). The free market existentialist: Capitalism without consumerism. Hoboken: Wiley Blackwell. (in English)

Rand, A. (1996). Atlas Shrugged. Kolkata: Signet. (in English)

Muntian, A. O., \& Shpak, I. V. (2015.). Atlas shrugged: Feminism discourse or discourse of femininity. Literatura $v$ konteksti kultury: Collection of scientific papers, 26(2), 141-146. (in English)

Camus, A. (1942). Le mythe de Sisyphe. Paris: Éditions Gallimard. (in French)

Heidegger, M. (1962). Die Zeit des Weltbildes. In F.-W. von Herrmann (Ed.), Holzwege (pp. 75-113). Frankfurt am Main: Klostermann. (in German)

Paton, H. J. (1962). Der kategorische Imperativ: Eine Untersuchung über Kants Moralphilosophie. Berlin: De Gruyted. (in German)

Nietzsche, F. (2007). Zur Genealogie der Moral. Eine Streitschrift. Zeno.org. Veine bibliothek. Retrieved from http://www.zeno.org/Philosophie/M/Nietzsche,+Friedrich/Zur+Genealogie+der+Moral (in German)

Peikoff, L. (1989). Fact and Value. The Intellectual Activist, 5(1). New York. (in English) 
Sartre, J.-P. (1956). L'etre et le neant: Essai d'ontologie phenomenologique. Paris: Librairie Gallimard. Retrieved from http://www.bard.edu/library/arendt/pdfs/Sartre-Neant.pdf (in French)

\section{LIST OF REFERENCE LINKS}

Cameron, D. Feminism and Linguistic Theory / D. Cameron. - Great Britain : Palgrave McMillan, 1992. - 247 p. Evans, S. M. Women's Liberation: Seeing the Revolution Clearly / S. M. Evans // Feminist Studies. - 2015. - Vol. 41, No. 1. - P. 138-149. Access Mode: https://www.bu.edu/wgs/files/2015/04/FS41-1_Sara_M._Evans-1.pdf

O’Connor, M. Ayn Rand, Girl-Power Icon [Virtual Resource] / M. O’Connor // The Cut. Feminism. - 2014. - 11 Nov. Access Mode: https://www.thecut.com/2014/11/ayn-rand-girl-power-icon.html - Title from Screen. - Date of Access: 21 April 2019.

Cleary, S. Philosophy Shrugged: Ignoring Ayn Rand won’t make her go away / S. Cleary // Newsletter. - 2015. - 22 June. - Access Mode: https://aeon.co/ideas/philosophy-shrugged-ignoring-ayn-rand-wont-make-her-go-away Title from Screen. - Date of Access: 21 April 2019.

Irwin, W. The Free Market Existentialist: Capitalism without Consumerism / W. Irwin. - Hoboken : Wiley Blackwell, 2015. - 133 p.

Rand, A. Atlas Shrugged / A. Rand. - Kolkata : Signet, 1996. - 1088 p.

Muntian, A. O. Atlas shrugged: Feminism discourse or discourse of femininity / A. O. Muntian, I. V. Shpak // Лiтepaтура в контексті культури : зб. наук. пр. - Київ : Видавничний дім Дмитра Бураго, 2015. - Вип. 26 (2). C. 141-146.

Camus, A. Le mythe de Sisyphe / A. Camus. - Paris : Éditions Gallimard, 1942. - 115 p.

Heidegger, M. Die Zeit des Weltbildes / M. Heidegger // Holzwege / M. Heidegger ; Hg. v. F.-W. von Herrmann. Frankfurt am Main : Klostermann, 1962. - P. 75-113.

Paton, H. J. Der kategorische Imperativ: Eine Untersuchung über Kants Moralphilosophie / H. J. Paton. - Berlin : De Gruyted, 1962. - 351 s.

Nietzsche, F. Zur Genealogie der Moral. Eine Streitschrift / F. Nietzsche // Zeno.org. Veine bibliothek. - 2007. Leipzig. - 118 p. - Access Mode: http://www.zeno.org/Philosophie/M/Nietzsche,+Friedrich/Zur+ Genealogie+der+Moral - Title from Screen. - Date of Access: 21 April 2019.

Peikoff, L. Fact and Value / L. Peikoff // The Intellectual Activist. - New York, 1989. - Vol. 5, № 1.

Sartre, J.-P. L'etre et le neant: Essai d'ontologie phenomenologique / J.-P. Sartre. - Paris : Librairie Gallimard, 1956. - 722 p. - Access Mode: http://www.bard.edu/library/arendt/pdfs/Sartre-Neant.pdf

\section{А. О. МУНТЯН ${ }^{1 *}$}

1* Дніпровський національний університет залізничного транспорту імені академіка В. Лазаряна (Дніпро, Україна), ел. пошта muntonya@gmail.com, ORCID 0000-0001-8375-4067

\section{ФІЛОСОФСЬКА РЕПРЕЗЕНТАЦІЯ ЖІНОЧИХ ХУДОЖНІХ ОБРАЗІВ В ОБ’ЄКТИВІЗМІ}

Мета. Грунтуючись на актуалізації гендерних дискурсивних особливостей, дана стаття присвячена дослідженню репрезентації, маніфестації, актуалізації та вербалізації взаємодії гендерно-філософських ідей: інтерпретація фемінізму в рамках об’єктивізму. Вихідним матеріалом даного дослідження є роман Айн Ренд "Атлант розправив плечі", який є філософською роботою з об'єктивізму. Теоретичний базис. Розвиток гендерного дискурсу, зокрема дискурсу фемінізму, досліджується під ретроспективним кутом. Дана стаття $\epsilon$ спробою виявити особливості репрезентації жіночих художніх образів в роботі Ренд і те, як роман Ренд вплинув на логічний розвиток дискурсу фемінізму. Дискурс фемінізму не є характерним для об’єктивізму, в якому поняття статі, як і гендеру, теоретично анулюється, оскільки гендер не має значення, як для особистого, так і для професійного зростання, проте практично приклади гендерної репрезентація та гендерної актуалізації широко представлені в філософії Ренд. Наукова новизна. У даній статті розглядаються відмінні риси гендерного дискурсу в об’єктивізмі. Результати грунтуються на застосуванні порівняльного аналізу. Стверджується, що, власне, сама філософія та основні філософські ідеї можуть бути виражені й сприйняті за допомогою творів художньої літератури. Такий твір - література з точки зору стилістики і синтаксису, але філософія з точки зору семантики, його художні образи стають прототипами філософських 
одиниць. Висновки. "Атлант розправив плечі" - це не тільки художня література, а й філософський трактат про об’єктивізм, який є філософією індивідуалізму, одноосібної боротьби і досягнення поставлених цілей. Жіночий образ протагоніста "Атлант розправив плечі" - образ Дегні Таггарт. Вона є переконаною прихильницею об’єктивізму. На думку Ренд, Дегні Таггарт - прототип істинної жінки утопічного американського капіталістичного суспільства, i саме їі художній образ був невірно витлумачений прихильниками ідей феміністського руху, а сама Дегні Таггарт стала іконою фемінізму, тоді як насправді дискурс Дегні Таггарт - це дискурс жіночності, оскільки Дагні непритаманне все, що пов'язано 3 феміністськими ідеями і практиками. Вплетення дискурсу Дегні Таггарт в більш широкий дискурс фемінізму є неправомірним, хоча їі дискурс може бути віднесений до дискурсу жіночності.

Ключові слова: стать; дискурс; фемінізм; жіночність; філософія об'єктивізму; філософське уявлення

\section{А. А. МУНТЯН ${ }^{1 *}$}

$1^{*}$ Днипровский национальный университет железнодорожного транспорта имени академика В. Лазаряна (Днипро, Украина), эл. почта muntonya@gmail.com, ORCID 0000-0001-8375-4067

\section{ФИЛОСОФСКАЯ РЕПРЕЗЕНТАЦИЯ ЖЕНСКИХ ХУДОЖЕСТВЕННЫХ ОБРАЗОВ В ОБЪЕКТИВИЗМЕ}

Цель. Основываясь на актуализации гендерных дискурсивных особенностей, данная статья посвящена исследованию репрезентации, манифестации, актуализации и вербализации взаимодействия гендернофилософских идей: интерпретация феминизма в рамках объективизма. Исходным материалом данного исследования является роман Айн Рэнд "Атлант расправил плечи", который является философской работой по объективизму. Теоретический базис. Развитие гендерного дискурса, в частности дискурса феминизма, исследуется под ретроспективным углом. Данная статья является попыткой выявить особенности репрезентации женских художественных образов в работе Рэнд и то, как роман Рэнд повлиял на логическое развитие дискурса феминизма. Дискурс феминизма не характерен для объективизма, в котором понятие пола, как и гендера, теоретически аннулируется, поскольку гендер не имеет значения, как для личного, так и для профессионального роста, однако практические примеры гендерной репрезентация и гендерной актуализации повсеместно представлены в философии Рэнд. Научна новизна. В данной статье рассматриваются отличительные особенности гендерного дискурса в объективизме. Результаты основаны на применении сравнительного анализа. Утверждается, что, собственно, сама философия и основные философские идеи могут быть выражены и восприняты посредством произведений художественной литературы. Такое произведение - литература с точки зрения стилистики и синтаксиса, но философия с точки зрения семантики, его художественные образы становятся прототипами философских единиц. Выводы. "Атлант расправил плечи" - это не только художественная литература, но и философский трактат об объективизме, который является философией индивидуализма, единоличной борьбы и достижения поставленных целей. Женский образ протагониста "Атлант расправил плечи" - образ Дэгни Таггарт. Она является убежденной сторонницей объективизма. По мнению Рэнд, Дэгни Таггарт - прототип истинной женщины утопического американского капиталистического общества, и именно ее художественный образ был неверно истолкован сторонниками идей феминистского движения, а сама Дэгни Таггарт стал иконой феминизма, тогда как на самом деле дискурс Дэгни Таггарт - это дискурс женственности, поскольку Дагни чуждо все, что связано с феминистскими идеями и практиками. Вплетение дискурса Дэгни Таггарт в более широкий дискурс феминизма есть неправомерным, хотя ее дискурс может быть отнесен к дискурсу женственности.

Ключевые слова: пол; дискурс; феминизм; женственность; философия объективизма; философское представление

Received: 21.11.2018

Accepted: 19.03.2019 